\title{
Finding Social Dilemma: West of Babel, not East of Eden
}

\author{
Richard E. Wagner \\ Department of Economics, 3G4 \\ George Mason University \\ Fairfax, VA 22030 USA
}

\begin{abstract}
This paper refracts Gordon Tullock's The Social Dilemma onto a framework of spontaneous order theorizing, and finds the refraction to work well. The Social Dilemma reveals Gordon Tullock to be a theorist whose conceptualizations are anchored in a societal setting represented better by networks than by fields, and where societal outcomes emerge out of local networked interaction. The theoretical orientation of The Social Dilemma is redolent with spontaneous order themes, including his adoption of a field of vision that looks for social order west of Babel and not east of Eden. The paper also makes some secondary effort to compare The Social Dilemma with James Buchanan's The Limits of Liberty.
\end{abstract}

Keywords: spontaneous order, social dilemma, social networks, emergent theorizing, Gordon Tullock, James Buchanan

JEL Codes: B4, D6, D7 


\section{Finding Social Dilemma: West of Babel, not East of Eden}

The purpose of this paper is to show the congruence between Gordon Tullock's The Social Dilemma and the theoretical core of spontaneously emergent processes of social ordering that is associated particularly strongly with the Scottish Enlightenment. ${ }^{1}$ During this exploration of Tullock's roots in spontaneous order theorizing, I shall also offer a few comparisons with James Buchanan's The Limits of Liberty. I do this for several reasons. First, the organizers of this Symposium asked that I do so. Second, Buchanan (1987) locates Tullock not as a theorist within the tradition of spontaneous order but as a theorist of homo economicus. Third, both books treat the same topic and were written about the same time, so it seems worthwhile to give some thought to similarities and differences between the two authors of the epochal The Calculus of Consent. Fourth, I have accumulated some intellectual capital on the topic, in that I have previously published appreciative essays on both Buchanan (Wagner 1987a) and Tullock (Wagner 1987b), as well as publishing a reflective essay (Wagner 2004) on the scholarly milieu they generated during their academic association over a third of a century.

I do not proceed in exegetical fashion by presenting a Reader's Guide to The Social Dilemma. An interested reader can do this easily. Rather, I place primary emphasis on exploring the theory of spontaneous order in relation to the conceptual framework on which The Social Dilemma rests. A person can be a creative economic and social theorist without thinking or writing much about methodology. Tullock has proceeded in this manner, as it is hard to find much by 
way of explicit methodology within his scholarly oeuvre. Yet Tullock, as any theorist, operates with underlying principles that govern his selection of material and the manner in which he explores that material. An examination of the foundations that support The Social Dilemma shows clearly that Tullock theorizes from a spontaneous order orientation.

A large part of my effort involves an elaboration of the framework of spontaneous order theorizing about social order in a way that reveals the spontaneous order core of Tullock's The Social Dilemma. What I attempt here is an imaginative act of scholarly bridging to connect two points of anchorage: (1) Tullock's The Social Dilemma and (2) the conceptual core of spontaneous order theorizing. Tullock's scholarly oeuvre contains no extended discussion of spontaneous order nor does the term appear in the Index to his Selected Works; nonetheless, The Social Dilemma reflects a deep understanding and appreciation of spontaneous order theorizing.

\section{Setting the Scene}

The Calculus of Consent quickly became a classic after its 1962 publication through its ability to articulate and inspire scholarly inquiry in what subsequently became known as public choice. As the authors noted in their Preface, the work was genuinely a joint product as each author worked on each chapter, with in many cases chapters going back-and-forth several times between the authors. The only indication of divergence appeared in their separate appendixes: Buchanan wrote about some precursors in political 
philosophy; Tullock wrote about some theorists who sought to develop a positive political theory. Those appendixes aside, it might seem as though those authors were unified in their underlying vision of social order and its problematical features.

Over the subsequent decade, Buchanan and Tullock published a good number of items jointly as well as each producing their customary torrent of individual manuscripts. Nothing they ever did again matched the influence of The Calculus of Consent, but one such work in a lifetime is more than most of us will ever experience. By the early 1970s, both authors were in Blacksburg at VPI. Anarchy was a topic of intense examination at the time, leading to two books edited by Tullock (1972)(1974). This scholarly milieu also led to Buchanan and Tullock each writing books that treated the same general theme of social order and the prospects for and limits of orderly and peaceful anarchy. Buchanan's book was, of course, The Limits of Liberty; Tullock's was The Social Dilemma. $^{2}$

Each author sent his manuscript to the University of Chicago Press. Obviously, Buchanan's was accepted. Equally obviously, Tullock's was not. Tullock subsequently published The Social Dilemma in the same series as the two collections he edited on anarchy. All three of Tullock's volumes were published by University Publications, which was the name Tullock gave to his private publication efforts in Blacksburg. Both books treated the same central theme of social order and its problematical features. For Buchanan that problematic was portrayed in terms of a tension between anarchy and leviathan, 
to borrow from Buchanan's subtitle. For Tullock, it centered on the continuing threat of war and revolution, along with coup d'états and dictatorships, to borrow also from his subtitle and to extend it. There is a good deal of complementarity in these works, but also some significant differences in orientation. They were published about the same time, and both were organized around the prisoners' dilemma. Yet the theoretical orientations they take to their material differ in subtle but significant ways.

When Nicolaas Vriend (2002) asked "Was Hayek an Ace?" he was engaging in an activity similar to what I am undertaking here. Vriend's reference to "Ace," it should be noted, was to agent-based computational modeling, which is described nicely in Mitchel Resnick (1994) and illustrated in action in Joshua Epstein and Robert Axtell (1996). Agent-based modeling provides a framework for allowing individual agents to differ in what they know and how they act, and with aggregate, societal-level formations emerging out of local interaction among such agents, in contrast to their being stipulated in advance through some postulation of societal equilibrium. Hayek's scholarship was developed well before agent-based computational modeling entered the intellectual arsenal. In no way could Hayek have taken recourse to agent-based modeling to explore and illustrate his ideas and insights about distributed knowledge. The intellectual technology for doing so was just not present when Hayek wrote. Yet it is reasonable to argue, as Vriend does, that Hayek's orientation toward his material is congruent with what could potentially be accomplished through agent-based computational modeling. 
A theoretical model is an instrument for casting illumination, but that illumination necessarily is cast only upon a subset of the potential territory a scholar might examine. Agent-based modeling does not force a scholar to think in terms of the use of distributed knowledge, but it does make it possible to illustrate and illuminate some of those insights, and to explore them in ways and manners that could not previously been explored. It is the same with my treatment of Tullock's The Social Dilemma in light of the theoretical framework of spontaneous social order. With respect to Buchanan's (1987) description of Tullock as a natural economist, that description would have been accurate had the quality "natural" referred to the underlying presuppositions that characterizes spontaneous order theorizing instead of referring to modeling isolated homo economicus. Tullock is a natural theorist of spontaneous ordering processes; even though he does not pursue methodological discourse, his substantive works reflect a thoroughgoing embrace of spontaneous order theorizing. Where Vriend (2002) describes Hayek as being an Ace, I would describe Tullock likewise as an Ace; moreover, Aces necessarily must be spontaneous order theorists.

\footnotetext{
Alternative Windows for Social Theorizing: Mengerian and Walrasian

People who think about objects like trees or frogs can apprehend their objects directly by inspection. People who think about objects like economy or polity or society cannot do so without the preceding adoption of some conceptual framework that brings that object into view. The properties possessed by that object depend on the window through which it is viewed. Social phenomena,
} 
unlike material objects, are not directly apprehensible by the senses, but can be perceived only through some prior conceptual framework or analytical window. A particular grocery store can be apprehended directly, as can the shopping center in which it stands. So, too, for that matter, can a city hall, a police station, a church, or a country club. Such objects as these reside inside the objects we denote as economy, polity, or society but do not constitute those objects. To be sure, most scholarly discourse takes place by treating their objects as if they were directly apprehensible, which seems to render unproblematic such objects as polity or economy, as distinct from particular material reflections of those objects. But this is just ordinary economizing action through following established convention. Economists speak continually of markets and market economies; nonetheless, the articulation of the central features of that object depends upon some preceding conceptual articulation of the nature of that object, even though it is possible for someone to enter into on-going dialogue without engaging explicitly in such articulation.

With respect to contemporary economic theorizing, there are two prime windows for viewing economic phenomena. Wagner (2007) labels these the Walrasian and Mengerian windows. I shall continue with that distinction here, though I recognize that other comparative designations are possible. This particular designation hearkens back to the late- $19^{\text {th }}$ century origins of the postclassical period of economic theorizing, as represented by Léon Walras and Carl Menger. It does not, however, map directly and easily into some disjunction between neoclassical and Austrian economics. For one thing, a good deal of 
Austrian theorizing after Menger took place through the Walrasian window, as noted especially clearly by Sandye Gloria-Palermo (1999). Furthermore, a growing body of non-Austrian scholarship on social complexity and evolution has been formulated while looking through a Mengerian-type window, as illustrated nicely by Jason Potts (2000).

What, then, is involved in the comparison between the Walrasian and the Mengerian windows? Both windows show orderly social processes, for all social theorizing starts from orderliness of some type because otherwise there would be no intelligible object to theorize about. The windows diverge in how they display the object being examined. The Walrasian window reduces a society to a snapshot-like structure of equilibrated relationships, with the intellectual challenge being to develop ever more subtle analytical stories that are consistent with the postulated equilibrium. While the Walrasian window construes societal observations as market equilibria, the key feature of this construal is the timeindependent character of the object. Meaning can be derived directly from the object without consideration of history, either what has been or what is yet to be. Among other things, plans, their stages of completion and their relationships to other plans are irrelevant because they are effectively neutered by the presumption of time-independent societal equilibrium. Successive views may show different equilibrium configurations, and such differences provide the central material for economic analysis within this type of research program. The analytical challenge when society is viewed through the Walrasian window is to 
give an account of the different equilibria in terms of utility-maximizing responses to exogenous events.

In contrast, the view of society through the Mengerian window provides images taken not from snapshots but from motion pictures. Human action and societal interaction involve duration, whereby today emerged out of yesterday and tomorrow will emerge out of today. Meaning and significance regarding social life require understanding of patterns of activity that cannot be reduced to a snapshot. Successive views through the Walrasian window can, of course, reveal a multiplicity of snapshots. Nonetheless, a snapshot is not a motion picture. It's easy enough to imagine taking several snapshots through a Walrasian window of a horse running. Some of those snapshots will show all four of the horse's hoofs to be off the ground. No one who looks at such a snapshot will say that it shows that a horse can fly, because knowledge to the contrary is brought to the snapshot. But in rejecting the claim that a horse can fly, the model provided within the Walrasian window is actually being rejected in that the model's false image is replaced by knowledge not accommodated within the model. The truth of the matter is not revealed by or within the model, but rather is imported from outside the model despite what the model itself appears to show about flying horses.

The truth of this situation can only be captured when theorizing through the Mengerian window because the passing of time is essential to capturing the reality of the activity represented by a running horse. For any setting where the 
passing of time is an essential feature of the activity under examination, the Mengerian and not the Walrasian window provides the right analytical lens. Meaning can't be ascertained from a snapshot, for snapshots cannot provide testimony about the processes that are generating our observations of societal phenomena.

The Mengerian window is congruent with spontaneous order theorizing; the Walrasian window is not. Within the Walrasian window, orderliness is presumed to exist, but that orderliness is itself in no way an object to be explained or understood. In contrast, the Mengerian window offers insight into the processes through which orderly patterns emerge and change. Spontaneous order speaks of emergent relationships, which in turn requires the analyst to think in terms of distinct planes of societal activity and existence. Societal formations are higher-level phenomena that emerge out of interactions among individuals at a lower level of analysis. Within the Mengerian analytical motif, social order and its characteristic features are emergent features of the economizing actions and interactions of the inhabitants of a society. Mengerian theorizing is spontaneous order theorizing, Walrasian theorizing is not. Tullock's The Social Dilemma is situated fully within the Mengerian motif.

\section{Spontaneous Order as Emergence-Based Theorizing}

While theorizing about spontaneous orders will always entail processes where time passes, the passing of time is not sufficient for spontaneous order theorizing to be suitable. What is also necessary is locally and not globally 
generated action by the constituent units of the relevant social formation. For this, society must be conceptualized in terms of networks of incomplete connectivity and not in terms of fields of complete connectivity, a distinction elaborated in Potts (2000, pp. 55-81). With a field, each node is connected directly to each other node. For a network, each node is connected only to some of the other nodes.

Consider two views of two streets seen through the Mengerian window. One street is named Marching Street, the other Shopping Street. Along both streets a large number of people are observed to be moving in orderly and intelligible fashion. The only difference in the two views is that the coordination among people seems more complete on Marching Street than it does on Shopping Street. On Marching Street everyone arrives at their destination exactly as they had anticipated; this outcome assimilates nicely to a model of competitive equilibrium. On Shopping Street not everyone finds their movement to proceed as they had anticipated; the movement would appear to be imperfectly coordinated when compared against the movement along Marching Street.

This point of this illustration, I should note, is not to invoke market failure on Shopping Street and to argue for trying to make Shopping Street look more like Marching Street, though a great deal of contemporary economic analysis proceeds in this fashion. To the contrary, my point is ontological in character, and concerns the need to operate with a theoretical framework that is suitable for the object of theorization. Two distinct types of motion are being observed on the 
two streets, and these call for distinct theoretical frameworks to render intelligible the societal patterns being observed.

What is being observed on Marching Street is a parade. The parade is equilibrated, with the parade marshal serving as the auctioneer. As a participant you will know within a minute or two when you will reach the end of the route; as a reviewer you can tell by your watch what outfit is now passing the reviewing stand. The only thing that can dash such rational expectations is some kind of exogenous shock. The two-hour parade starts in 70 degree sunshine, but 30 minutes after the start, the sky darkens, the temperature drops 20 degrees, severe lightening is seen in the distance and is quickly coming near. So the marshal shifts to double time and eliminates any performances before the reviewing stand. The parade ends 45 minutes ahead of schedule, with many people left without rides to pick them up. There is an exogenous shock to a precoordinated social order, but it has nothing to do with spontaneous order or economic theorizing.

What is being observed on Shopping Street are not the participants in a parade who are coordinated by a parade marshal, but the numerous people who are conducting the various activities that are part of their daily lives. Observation shows the motion on Shopping Street to be reasonably well coordinated, even though not as fully as it is on Marching Street. Any such comparison of the activity on one street in terms of the activity on the other is to pretend to compare incommensurable objects. The movement along Shopping Street illustrates a spontaneously ordered social pattern. The pattern of motion will be orderly, but 
not everyone will have their expectations fulfilled exactly. For instance, someone rushing to a jewelry store to pick up an engagement ring to bestow that evening may get knocked down by someone rushing to catch a taxi, thereby missing the traffic signal that just turned red and thus missing the closing of the jewelry store by 45 seconds. In consequence, there is, perhaps, a proposal of marriage that is rejected because of its tardiness. Alternatively, a marriage might have resulted six months later as a result of a collision between two people whose arms were filled so high with packages that they couldn't see one another, and would never have met were it not for the unanticipated collision.

In any case, and more generally, un-intentionality as well as intentionality is an integral part of evolving social processes. Spontaneous order theorizing requires scope both for intentional human action and unintended resultants of interaction among human intentionalities. Each person walking down the street has intention and is engaged in economizing action. The overall societal pattern, moreover, is generally orderly though not exactly or fully. A marching band is outside the ambit of spontaneous order theorizing. So is any economic theorizing that posits societal equilibrium as an analytical point of departure, as against possibly positing equilibrium as a mental tool that provides a point of departure for further thought. Standard representative agent theorizing thus reflects postulated order and not spontaneous order.

Spontaneous order should not be analogized to spontaneous combustion, and it is perhaps unfortunate that the two terms are so similar. Spontaneous combustion refers to combustion without intentionality, as when a pile of rotting 
grass ignites due to the generation of heat. Spontaneous order theorizing has nothing to do with spontaneous combustion. Tullock (2005, pp. 201-24) gives extensive consideration to claims of spontaneous combustion in human societies and finds such claims to be nonsensical precisely because such claims do not allow for the intentionality that is necessary for societal motion. Tullock's particular object of examination is the claim that sometimes a popular uprising just happens for no particular reason, much as rotting grass might suddenly catch fire. Being a good Humean skeptic, Tullock does not assert that a popular rising is beyond any possible pale of imagination, but rather notes that no such rising has yet been sighted. Behind societal motion of any form will reside intention, typically multiple intentions whose interaction generates the phenomenon being observed.

Spontaneous order in human societies refers to unintended qualities of the interaction among intentions. Spontaneous order does not come into play when theorizing pursues a field-based notion of equilibrium, as is followed by much contemporary economic theorizing. An economist who works exclusively with maximizing models of homo economicus outside of any concern with interaction, such as characterizes equilibrium-based theorizing, is not a spontaneous order theorist. Homo economicus is a terribly abused notion among economists, but not by Tullock. Homo economicus involves nothing more than the claim that people try to succeed and not fail at what they attempt. Perhaps the man who tried to kill himself by stepping in front of a train, only to survive in mangled form, might illustrate a denial of homo economicus. Within the normal contours of life, 
however, denial is surely absurd. Albert Schweitzer giving up his comfortable life as a prominent theologian in Germany to become a missionary in Africa is as much an illustration of homo economicus as is Adolf Hitler, who stayed home. A universal desire to be effective and not ineffective in one's chosen actions and projects leaves open both the choice of ends and the cognitive beliefs that connect means to ends.

It is perhaps particularly interesting to note that Chicago-style economic modeling is antithetical to spontaneous order theorizing, at least as Chicago-style modeling is characterized by Melvin Reder (1982). There, Reder argues that Chicago-style economic theorizing proceeds on the basis of two hard-core assumptions regarding social observations: (1) individuals maximize utility functions and (2) markets clear. In doing this, Reder locates Chicago-style theorizing within the Walrasian window and removes it from the ambit of spontaneous order theorizing. This removal obviously clashes with the theoretical orientation articulated by Milton Friedman in the 1940s and is still widely associated with the appellation "Chicago-style." I have particularly in mind Friedman's essays on Alfred Marshall, Oskar Lange, and Abba Lerner, all reprinted in Friedman (1953). There, Friedman articulated a disjunction between Marshallian and Walrasian motifs, in place of my disjunction between Mengerian and Walrasian motifs. In Friedman's formulation, the key difference was between partial and general equilibrium. This distinction did not hold in the hands of Friedman's successors, I think at least partly for understandable reasons. Partial signifies something that is incomplete relative to something that 
is general: A partial explanation of something is better than no explanation, but a general explanation is better still. While Marshall himself was deeply concerned with exploring development through time, once time vanished from being integral to the understanding of societal activity and formations, the replacement of Marshall by Walras was at hand. While Marshall theorized through the Mengerian window, the focus on partial equilibrium and not the time-dependent character of human action and social organization led to the transference of the Marshallian orientation into the Walrasian window.

To be sure, Chicago-style theorizing is noted for the libertarian bent of its practitioners. But libertarian refers to some claims about the desirable or necessary extent of force in the ordering of human affairs. One can easily assert that social observations map nicely into the necessary conditions for competitive equilibrium, thereby asserting somewhere between a small and null scope for state action to complete that order, without being a theorist of spontaneous order. Spontaneous order theorizing is not another name for libertarian, even though one certainly can be both libertarian and a theorist of spontaneous order. However, one can also be a theorist of spontaneous order without being a libertarian, as illustrated by Jacob Viner's (1961) chiding of Friedrich Hayek (1960). Alternatively, Thomas Schelling's (1978) treatment of the emergence of macro formations out of micro-level choice and interaction is a wide-ranging illustration of spontaneous order theorizing without bringing libertarian presumptions in its train. 


\section{Game Theoretic Views of Social Dilemma: Outside-In or Inside-Out?}

The Social Dilemma, as well as The Limits of Liberty, uses the prisoners' dilemma as the central framework for organizing and carrying forward its various lines of argument, as, for that matter, does most work in this area. The familiar Hobbes-like formulation conveys the idea that while both parties prefer peace to war, they also don't want to be caught napping while the other party attacks, and so war prevails over peace (or at least peace is only a temporary and not a permanent condition). All theorizing requires a theorist who contemplates an object, so some detachment or distance must be created between the theorist and the object. The theorist is a spectator to and not a participant within the object being analyzed. A cardinal feature of spontaneous order theorizing nonetheless is for the theorist to seek to render intelligible the phenomena being observed through people pursuing their desires and plans through interaction with others inside society. Societal formations, in other words, are built up from the inside-out in bottom-up fashion, as against being conceptualized from the outside-in in top-down fashion.

Game theoretic formulations within a framework of postulated order proceed through what can be described as outside-in logic. In contrast, game theoretic formulations articulated within a framework of spontaneous order will proceed through inside-out logic. Outside-in logic starts with given strategies and payoffs, and then inquires into the character of rational conduct. Inside-out logic starts with people inside a setting of interaction, and recognizes that strategies and payoffs are created by the participants through interaction. Within this 
alternative logic, any notion of given initial conditions is but a first-draft point of analytical departure, and most certainly not some given fact imposed upon the participants and immune from modification.

The customary view is from the outside looking in. In contrast, Tullock's analysis largely proceeds from the inside looking out even though he starts with a standard presentation of the prisoners' dilemma. At its simplest, most elemental level the prisoners' dilemma conveys a story of desires frustrated by human nature. The austere form of the prisoners' dilemma illustrates modeling from the outside looking in. The structure of the game is in place, as represented by its payoff matrix. Faced with this matrix, the players have no option but to realize their fates. The players are reluctant duelists, to recall Daniel Ellsberg (1956). Much modeling that uses game theory works with the outside looking in framework, and with the result often being to derive solutions that are not Pareto efficient from the standpoint of the players, as illustrated cogently by Peyton Young (1998).

But game theory can also be approached from the inside looking out. In this case the fate dictated by the original game matrix does not necessarily control the players and the outcomes they realize, because the players can speak back as it were. In doing this, the game matrix can be transformed in various possible ways. What allows for numerous possible story lines to be developed from this simple template occurs when we move inside the model. Often this transformation occurs in ways that are not even noticed. The original prisoners' dilemma, for instance, is not adequately represented by the Hobbes- 
like dilemma because the original formulation had three players and not two. There were two prisoners who were put into the situation described by the dilemma by a district attorney. So a full description of the situation requires three people, one of whom forces the other two into the situation described by the PD matrix, and with those other two being reluctant duelists.

The situation is different if we start with just two people in the first place, as the Hobbes-like formulations do. In the original illustration, the district attorney stood apart from the prisoners and imposed the game matrix on them. But if we take away the district attorney, what remains? We observe two people who fight for awhile and then quit, one perhaps significantly more battered than the other. What do we conclude from this observation? One framework to impose is the PD framework. But what makes this framework so compelling? Or is it really so compelling?

Put differently, is it truly possible to recognize a PD situation, other than its imposition onto some set of people by some outside figure, as illustrated by the original illustration? We observe two people fighting, and that is all we observe. It's understandable that a post-fight interview might show the loser expressing regret. And even the winner might, and yet these twin observations wouldn't warrant the veracity of a PD claim. For the winner the expression of regret might indicate simply that he would have liked to have obtained the spoils of victory with less of a struggle, without, however, relinquishing the desire to obtain those spoils. 
Hence, the situation is not a PD but a conflict over who will be First Violin, as it were. Conflict is an inescapable and often valuable element of social order, as explained by Louis Coser (1956). For instance, property rights denote and delimit the settlement of conflict; conflict and property exist in a complementary relationship of yin-and-yang. Tullock's treatment of conflict throughout The Social Dilemma reveals that his thought proceeds in an inside-out manner suitable for network-based theorizing. Tullock follows standard PD formulations in labeling conflict a source of societal inefficiency. But he neither stays there nor asserts the desirability of some one-shot act of constitutional resolution. Tullock works with the network-grounded recognition that conflict is endemic and inescapable. To be sure, Tullock expresses some dismay at his "somewhat gloomy conclusions" (Tullock 2005, p. 368) in this regard, but I think this assessment of gloominess is a remnant of his once having peeked through the Walrasian window and seen mutual agreement as a concordant means of abolishing conflict forever.

Tullock is neither gloomy nor pessimistic. He is nothing if not a sober realist. There is plenty of reason to think that conflict with be with us always. Among other things, property rights are nothing but the residues of conflicts that have been settled, for now anyway though not forever. Fifty years ago you could have smoked a cigarette nearly anywhere you chose. This is not so today. Property rights have been modified through conflict. These ebbs and flows in the range of allowable human actions is something that Tullock neither applauds nor bemoans, but simply recognizes that these are a continuing feature of life in 
society. In other words, for Tullock the Social Dilemma is not a state of affairs to be escaped through appropriate constitutional action but rather is an eternal condition of life in human societies. Within such societies, the force of the dilemma might be ameliorated to some extent, but it won't be abolished.

A wonderful illustration of Tullock's thought in this respect is his treatment of mutual disarmament (Tullock 2005, pp. 311-53). The standard PD formulation would portray the options as arm and disarm, and would conclude that both parties could capture gains if they would disarm. The basic PD model says this won't happen, but the constitutional gloss on this model advances the prospect for some constitutional route of escape, an escape about which Tullock is skeptical. Regardless of whether that constitutional route is open or closed, Tullock explores the PD formulation from the inside looking out. When he does this, he sees that mutual disarmament will make war more likely because it has made war more profitable for both potential participants. If disarmament imposes proportionate reductions on the power of each participant, it will have had no effect on the probabilities of waging a successful war. After disarmament, however, a successful war of conquest can be waged more cheaply by the conquering power and, moreover, will inflict less damage on the conquered nation, thereby increasing its value to the conquering nation.

\section{Looking for Social Dilemma: East of Eden or West of Babel?}

Philosophers of science note that any theorist operates with some hard core propositions from which the analytical efforts spring, and with those 
propositions themselves being taken as given data for analytical purposes. Those hard core propositions are species of creation myth, in that they provide the raw fuel that propels the subsequent analytical efforts. Any analysis must have a point of origin. Theists posit God, as illustrated by the assertion (John 1:1) that "In the beginning there was the Word, and the word was God." Atheists posit the primeval concentration of energy that suddenly exploded billions of years ago. In either case a creation myth is invoked to generate a starting point, simply because we must start somewhere.

Every analysis of social dilemmas, Tullock's, Buchanan's, or anyone else's, invokes a creation myth to initiate and frame the analysis. Most theorizing that invokes a social dilemma starts by looking east of Eden for its material. (To be sure, Eden involved only two people, so Post-Flood might present a more apt even if less literary setting, because eight people offer a richer menu of interactive possibilities than do two.) In any event, the east of Eden motif envisions a concordant constitutional moment, with discord arising later during post-constitutional action. Buchanan's conceptual framework in Limits of Liberty illustrates an East of Eden motif.

In contrast, Tullock's creation myth draws its material by looking west of Babel. This alternative motif is grounded in significant discord and not universal concord. The eight who disembarked from the Ark were a concordant lot; those who left Babel were a discordant mélange of humanity. The view west of Babel was a mixture of concord and discord. This view is found throughout Tullock's 
The Social Dilemma, as illustrated particularly clearly in his examination of coups d'état as well as in his treatment of redistribution.

It is tempting, however, to model life west of Babel as a form of parable of the tribes, after Andrew Schmookler (1984). If this were done, concord would prevail within a tribe while discord prevailed among tribes. To take this step would threaten to transform the view west of Babel into a series of views east of Eden, just as the Mengerian-like features of the Marshallian view were transformed into the Walrasian view in post-Friedman Chicago. For what would now result would be concord within tribes and discord among tribes. Concord is represented by a field, so each tribe would now be represented as a field and not a network. The relationship among tribes would still be represented as a network, and in this context it would be possible to examine the waxing and the waning of size of various tribes within the network, as well as changes in the pattern or degree of concord and discord among the tribes.

Tullock engages in such theorizing himself when he examines balance of power as a means of preserving a good deal of peace by planning continually for war (Tullock 2005, pp. 354-67). Yet Tullock does not really conceptualize the individual tribes as fields but rather as networks. Hence, there is discord within tribes as well as across tribes. This alternative conceptualization is particularly evident in Tullock's various considerations of coups d'état. Coups are networkbased and not field-based phenomena. At any moment, one person might occupy the node labeled dictator. But we may be assured that many people aspire to hold that node. While other people scheme about how to take 
possession of that node, dictators must scheme about how to maintain their possession. They have many tools for doing this, all of which lower their actual wealth relative to what it would have been had it not been necessary to deploy resources to the task of staying in power. It is similarly easy to understand why rich people install more elaborate and expensive security systems to their homes than do ordinary people.

This difference in creation myth illustrates the difference between working with closed and open analytical models. Where most treatments of social dilemmas work with closed models, Tullock works with an open model. The Walrasian window presents the world as a closed, equilibrated model; the Mengerian window presents it as an open, evolving model, even as the particular shapes that evolution brings conform to higher-order patterns that remain eternally recognizable. For one who works with open concepts, as illustrated cogently by Vincent Ostrom (1997), it is quite reasonable to agree with Heraclitus that you can't step into the same river twice while at the same time agreeing with Ecclesiastes that there is nothing new under the sun.

Most social theorizing uses closed concepts, as illustrated by single-exit modeling. Rational choice models are typically framed by closed concepts, which mean that any person will invariably make the same choice when faced by the same setting. Most economists take recourse to single exit modeling framed by closed concepts. Such modeling works pretty well much of the time, but not always. Coups occur within dictatorships, even though most of the time they do not. A model of a dictator as a simple utility maximizer with secure property 
rights would seem to work much of the time. Yet what allows that model to work so well is that dictators do not simply accept or presume that they hold their positions securely, and so are acting continually to maintain their positions against threats about which they are never fully aware. The dictator thus confronts an open world even if a theorist treats it as if it were closed.

\section{Tullock as Spontaneous Order Theorist}

Gordon Tullock has never engaged in rumination or reflection on the foundations on which his thought rests. Nonetheless, his scholarly oeuvre, like any scholar's oeuvre, does have some founding creation myth that inspires the analytical effort. Reading The Social Dilemma shows clearly that Tullock's conceptual framework is congruent with notions of spontaneous order even if he exhibits no self-consciousness about ontological matters. Gordon Tullock is a theorist of open, evolving social order as was Heraclitus, but at the same time he also recognizes with Ecclesiastes that there are permanent features of the human drama that generates the social dilemma that he thinks will be with us always. 


\section{References}

Buchanan, James M. 1975. The Limits of Liberty. Chicago, University of Chicago Press.

Buchanan, James M. and Gordon Tullock. 1962. The Calculus of Consent. Ann Arbor, University of Michigan Press.

Buchanan, James M. 1987. "The Qualities of a Natural Economist." In Charles K. Rowley, ed. Democracy and Public Choice: Essays in Honor of Gordon Tullock. Oxford: Basil Blackwell, pp. 9-19.

Buchanan, Mark. 2002. Nexus: Small Worlds and the Groundbreaking Theory of Networks. New York: W. W. Norton.

Coser, Lewis. 1956. The Functions of Social Conflict. New York: Free Press. Daiches, David; Peter Jones; and Jean Jones. 1986. A Hotbed of Genius: The Scottish Enlightenment, 1730-1790. Edinburgh: Edinburgh University Press.

Ellsberg, Daniel. 1956. "The Theory of the Reluctant Duelist." American Economic Review 46: 909-23.

Epstein, Joshua and Robert Axtell. 1996. Growing Artificial Societies: Social Science from the Ground Up. Cambridge, MA: MIT Press.

Friedman, Milton. 1953. Essays in Positive Economics. Chicago: University of Chicago Press.

Gloria-Palermo, Sandye. 1999. The Evolution of Austrian Economics: From Menger to Lachmann. London: Routledge. 
Hayek, Friedrich A. 1960. The Constitution of Liberty. Chicago, University of Chicago Press.

Ostrom, Vincent. 1997. The Meaning of Democracy and the Vulnerability of Democracies. Ann Arbor: University of Michigan Press.

Potts, Jason. 2000. The New Evolutionary Microeconomics: Complexity, Competence, and Adaptive Behaviour. Cheltenham, UK: Edward Elgar.

Reder, Melvin W. 1982. "Chicago Economics: Permanence and Change." Journal of Economic Literature 20: 1-38.

Resnick, Mitchel. 1994. Turtles, Termites, and Traffic Jams: Explorations in Massively Parallel Microworlds. Cambridge: MIT Press.

Schelling, Thomas C. 1978. Micromotives and Macrobehavior. New York: Norton.

Schmookler, Andrew Bard. 1984. The Parable of the Tribes: The Problem of Power in Social Evolution. Berkeley: University of California Press.

Tullock, Gordon, ed. 1972. Explorations in the Theory of Anarchy. Blacksburg, VA: University Publications.

Tullock, Gordon, ed. 1974. Further Explorations in the Theory of Anarchy. Blacksburg, VA: University Publications.

Tullock, Gordon. 1987. Autocracy. Boston: Kluwer Academic Publishers.

Tullock, Gordon. 1974. The Social Dilemma: the Economics of War and Revolution. Blacksburg, VA: University Publications. 
Tullock, Gordon. 2005. The Social Dilemma: Of Autocracy, Revolution, Coup d' Etat, and War, vol. 8 of "The Selected Works of Gordon Tullock," ed. by Charles K. Rowley. Indianapolis: Liberty Fund.

Viner, Jacob. 1961., "Hayek on Freedom and Coercion." Southern Economic Journal 27: 230-36.

Vriend, Nicolaas J. 2002. "Was Hayek an Ace?" Southern Economic Journal 68: 811-840.

Young, H. Peyton. 1998. Individual Strategy and Social Structure. Princeton, NJ: Princeton University Press.

Wagner, Richard E. 1987a. "James . Buchanan: Constitutional Political Economist," Regulation 11 (February): 13-17.

Wagner, Richard E. 1987b. "Gordon Tullock as Rhetorical Economist." In Democracy and Public Choice: Essays in Honor of Gordon Tullock, ed. by Charles K. Rowley (Oxford: Basil Blackwell), pp. 27-38.

Wagner, Richard E. 2004. "Public Choice as an Academic Enterprise: Charlottesville, Blacksburg, and Fairfax Retrospectively Viewed." American Journal of Economics and Sociology 63: 55-74.

Wagner, Richard E. 2007. "Value and Exchange: Two Windows for Economic Theorizing. Review of Austrian Economics 20: forthcoming.

Watts, Duncan J. 1999. Small Worlds: The Dynamics of Networks between Order and Randomness. Princeton, NJ: Princeton University Press. 


\section{Endnotes}

${ }^{1}$ For a nice survey of people and ideas regarding the Scottish Enlightenment, see David Daiches, Peter Jones, and Jean Jones (1986). It should perhaps also be noted that spontaneous order theorizing is absent from the bulk of contemporary economic theorizing.

${ }^{2}$ I should offer some clarification about my references to The Social Dilemma. To this point I have referred to its original publication in 1974. Later, I shall describe The Social Dilemma as Tullock (2005) and not Tullock (1974). This alternative reference is to volume 8 of Tullock's Selected Works, which is now the volume that is available. This book, however, is an amalgamation of Tullock (1974) and Tullock (1987), which is Tullock's subsequent treatment of autocracy. The spontaneous order orientations of the two books by the same name are identical, but a reader should note that subsequent references to The Social Dilemma will sometimes actually be references to Tullock's Autocracy. This situation will cause no confusion to a reader who has seen only Tullock (2005), but a reader who has seen only Tullock (1974) may find attributions to The Social Dilemma that do not appear there because they appeared in Tullock (1987) instead. 